\title{
COMPARATIVE CLINICAL STUDY OF BHALLATAKADI CHURNA AND ERANDA SNEHA IN THE MANAGEMENT OF AMAVATA WITH SPECIAL REFERENCE TO RHEUMATOID ARTHRITIS
}

Khot Varsha Sadashiv*

Assistant Professor, Department of Kayachikitsa, Yashwant Ayurved College Kodoli, Dist. Kolhapur, Maharashtra, India

Received on: 09/10/14 Revised on: 19/11/14 Accepted on: 23/12/14

*Corresponding author

Dr. Khot Varsha Sadashiv, Assistant Professor, Department of Kayachikitsa, Yashwant Ayurved College Kodoli, Tal. Panhala, Dist. Kolhapur, Maharashtra, India. Pin Code.416 114. E-mail: drvarshaskhot@gmail.com

DOI: 10.7897/2277-4343.0619

\section{ABSTRACT}

Amavata is most crippling joint disease. With the passage of time most of the dietary habits, changing lifestyle and environment have been contributing number of diseases like Amavata which have become a challenge to the human race. Management of this disease is merely insufficient in other systems of medicine and patients are continuously looking for treatment from Ayurveda to overcome this challenge. The aim of this study was to evaluate the efficacy of study drugs in the management of Amavata and their effect on Rheumatoid Factor (RA) Factor. In the present clinical study, 60 patients of amavata were registered from the out patient department and indoor patient department of Yashwant Dharmarth Hospital, Kodoli, Kolhapur, Maharashtra, India. The patients in group I (20 patients) were given Bhallatakadi Churna, patients in group II (20 patients) were given Eranda tail and the patients in group III (20 patients) were given Bhallatakadi Churna along with Eranda tail. Patients treated with group III had better relief in most of lakshanas of disease and also improvement in objective criteria like RA Factor, ESR and C reactive proteins. The improvement was statistically significant in all three groups, but comparatively group III shown more significant relief.

Keywords: Amavata, Rheumatoid arthritis, Bhallatakadi Churna, Eranda tail, RA Factor.

\section{INTRODUCTION}

With the passage of time most of the dietary habits, changing lifestyle and environment have been contributing number of diseases like Amavata which have become a challenge to the human race. The chief pathogenic factors ama and vata are contradictory in nature so difficulty in planning the line of treatment. Amavata can be equated with Rheumatoid arthritis an inflammatory autoimmune joint disorder. Many previous studies were carried out in field of Ayurveda for treating amavata and got significant results also ${ }^{1,2}$ but here efforts are made for assessing effect of Ayurvedic drugs in the management of amavata along with their effect on RA Factor. Rheumatoid arthritis is autoimmune joint disorder having prevalence ranged $0.12 \%$ to $0.75 \%$. It is a depilating disease and continues pose challenge to physicians due to its morbidity and crippling nature. Hence the management of this disease is merely insufficient in other systems of medicine and patients are continuously looking with a hope towards Ayurveda to overcome this challenge.

\section{Aims and Objectives}

- To assess the efficacy of Bhallatakadi churna and Eranda sneha in amavata.

- To assess the result of both drugs on R.A. Factor.

\section{MATERIALS AND METHODS Conceptual study}

Detailed study of Amavata in relation to rheumatoid arthritis along with the review of drugs chosen for study from all available books and internet was carried out.

\section{Clinical Study}

- Subjects attending Kayachikitsa OPD and IPD of Yashwant Ayurved Hospital Kodoli, India were selected for study.

- Subjects were selected by randomized method. Ethical Clearance number granted for this study was MUHS/PG/E-3-T/3210/315

\section{Inclusion Criteria}

- Subjects of age between 20-65 years.

- Either sex

- Subjects having sandhishool, sandhishoth, sandhistabdhata, sparshaasahatva and associated lakshnas of amavata

\section{Exclusion criteria}

Subjects having major illness and prediagnosed of Hypertension, HIV, Diabetes mellitus, Rheumatic fever and allergic to Bhallataka were excluded from the study. 


\section{Withdrawal criteria}

- Subjects unwilling for treatment.

- Any adverse reaction occurs.

\section{Trial Drug Schedule}

20 patients were selected randomly in each group and treated as (Bhallatakadi churna $1 \mathrm{~g}$ BID for group I); (Eranda tail $10 \mathrm{ml} \mathrm{OD}$ for group II) and (both drugs for group III)

Duration of treatment: 30 days.

Follow up: Day- $15^{\text {th }}, 30^{\text {th }}$

References of trial drugs: Yogratnakar amavatachikitsa.,

\section{Criteria for assessment}

- Relief in the cardinal and associated lakshnas of amavata was assessed by using a special scoring system.

- Improvement in laboratory parameters RA Factor, ESR, C reactive protein, DLC (differential leucocytes count).

- Functional assessment was done by measuring walking time, grip strength, general functional capacity and fatigue.

- Improvement in general health.

- The obtained data were statistically analyzed by applying test like chi square test. ${ }^{6}$

\section{Total effect of therapy}

The obtained results were graded as follows.

Complete remission: $100 \%$ relief

Marked improved: $>50 \%$ reliefs

Improved: $25 \%$ to $50 \%$ relief

Unchanged: $<25 \%$ relief or no relief

\section{Observations}

Each group contains 20 patients. All patients completed the treatment. In this study $33.33 \%$ patients were from age group 51-65 years and $30 \%$ patients were from age group 31-40 years. $65 \%$ patients were male whereas 35 $\%$ patients were female. Which means evidence of Amavata is prevalent in Female particularly in the area of study. In $8.3 \%$ patients having family history of Amavata while $6.6 \%$ patients having tobacoo addiction, $6.6 \%$ having tobacoo powder (mishri) addiction, $1.6 \%$ having Cigarette addiction. In the present study, majority of the patients i.e. $33.33 \%$ reported chronicity ranging between $>1$ to $<=3$ years, $16.66 \%$ patients were having the chronicity $<=1$, chronicity of $>3$ to $<=5$ were $21.66 \%$ and $>7$ to $<=10$ years was present in $13.33 \%$ of patients and $8.3 \%$ patient were having chronicity of $>5$ to $<=7$ and rest of $6.66 \%$ patients having chronicity of $>10$. In the present study, majority of the patients i.e. $30 \%$ were of Vatakapha prakriti and 26.66\% and $21.66 \%$ of patients were having Vatapitta and Kaphavata prakriti respectively.

\section{RESULTS}

In present study Table 1 shows percentage of relief in sandhishool in three groups patients $50 \%, 55 \%, 85 \%$ respectively. Results were significant in Group III than other groups. There was significant difference in the results of three groups on Sandhishool.

Table 2 shows percentage of relief in sandhishotha in three groups patients $60 \%, 85 \%, 90 \%$ respectively. There was significant difference in the results of three groups on Sandhishoth.

Table 3 shows percentage of relief in sandhisthabdhata in three groups patients $60 \%, 65 \%, 75 \%$ respectively. There was no significant difference in the results of three groups on Sandhistabdhata.

Table 4 shows relief of Spashaasahatva observed in group I $(75 \%)$, in group II $(75 \%)$ and in group III $(80 \%)$ patients. There was no significant difference in the results of three groups on Sparshaasahatva.

Percentage of relief in angamarda in three groups patients were $65 \%, 55 \%, 90 \%$ respectively in lakshana aruchi. Percentage of relief in three groups patients were $83 \%$, $61 \%, 94 \%$ respectively.

Percentage of relief in Trishna in three groups patients were $57 \%, 69 \%, 76 \%$ respectively.

Percentage of relief on Aalsya in three groups patients were $70 \%, 62 \%$ and $75 \%$ respectively.

Relief of Gourav observed in three groups patients were $46 \%, 52 \%, 69 \%$ respectively.

Relief in Jwar observed in group I (70 \%), in group II (18 $\%)$ and in group III (66\%) patients.

Relief of Apaka observed in group I ( $87 \%$ ), in group II $(30 \%)$ and in group III $(70 \%)$ patients.

Relief of shoonata anganam observed in group I (25\%), in group II and group III (80 \%) patients.

Group I shows statistically significant results $(\mathrm{P}<0.05)$. Groups II and III show statistically highly significant results $(\mathrm{P}<0.01)$ in RA Factor. Significant reduction in the RA Factor level was obtained in group I (60\%) and group II (60\%) while in group III (75\%) patients.

Table 5 shows significant difference in the efficacy of three groups on RA Factor. Effect of therapy on E.S.R. Group I was highly significant at level of $p<0.001$ and Group III was statistically significant $(\mathrm{P}<0.01)$. Effect of therapy on C.R.P. Groups I and III was statistically significant $(\mathrm{P}<0.05)$. Effect of therapy on Grip Power Groups I and III were statistically significant $(\mathrm{P}<$ $0.01)$.Group II was significant at the level of $p<0.05$. Effect on walking time Group II was statistically significant $(\mathrm{P}<0.05)$ while Group III was statistically 
highly significant $\mathrm{p}<0.01$. Effect on general functional capacity Groups I was statistically significant $(\mathrm{P}<0.05)$. Group II and III were statistically highly significant at the level of $\mathrm{p}<0.01, \mathrm{p}<0.001$ respectively. The general functional capacity of patients in group I showed an improvement of $25 \%$ and in group II $25 \%$, in group III $55 \%$. Improvement in fatigue shows statistically highly significant results. In Group III and I results were ( $\mathrm{p}<$ $0.001)$ and $(p<0.01)$ respectively. The data of the present series reveals that in Group I out of 20 patients, none of the patients got complete remission, 13 patients $(65.00 \%)$ markedly improved, 7 patients $(35.00 \%)$ improved and none of patients remained unchanged. (Table 6)

Table 1: Effect of therapy on Sandhishool

\begin{tabular}{|c|c|c|c|c|c|c|c|c|}
\hline Group & $\begin{array}{c}\text { Number of } \\
\text { patients }\end{array}$ & Relief & $\begin{array}{c}\text { No } \\
\text { change }\end{array}$ & $\begin{array}{c}\text { Percentage of } \\
\text { relief }\end{array}$ & $\begin{array}{c}\text { Chi -Square } \\
\text { value }\end{array}$ & Df & "P" value & $\begin{array}{c}\text { Significant/ } \\
\text { Insignificant }\end{array}$ \\
\hline I & 20 & 10 & 10 & 50 & \multirow{2}{*}{6.17} & 2 & \multirow{2}{*}{ Significant } \\
\cline { 1 - 5 } II & 20 & 11 & 9 & 55 & & & \\
\end{tabular}

Table 2: Effect of therapy on Sandhishotha

\begin{tabular}{|c|c|c|c|c|c|c|c|c|}
\hline Group & $\begin{array}{c}\text { Number of } \\
\text { patients }\end{array}$ & Relief & $\begin{array}{c}\text { No } \\
\text { change }\end{array}$ & $\begin{array}{c}\text { Percentage of } \\
\text { relief }\end{array}$ & $\begin{array}{c}\text { Chi -Square } \\
\text { value }\end{array}$ & Df & "P" value & $\begin{array}{c}\text { Significant/ } \\
\text { Insignificant }\end{array}$ \\
\hline I & 20 & 12 & 8 & 60 & \multirow{2}{*}{6.088} & 2 & \multirow{2}{*}{ Significant } \\
\hline II & 20 & 17 & 3 & 85 & 90.05 & \\
\hline III & 20 & 18 & 2 & 90 & & \\
\hline
\end{tabular}

Table 3: Effect of therapy on Sandhistabdhahta

\begin{tabular}{|c|c|c|c|c|c|c|c|c|}
\hline Group & $\begin{array}{c}\text { Number of } \\
\text { patients }\end{array}$ & Relief & $\begin{array}{c}\text { No } \\
\text { change }\end{array}$ & $\begin{array}{c}\text { Percentage of } \\
\text { relief }\end{array}$ & $\begin{array}{c}\text { Chi -Square } \\
\text { value }\end{array}$ & Df & "P" value & $\begin{array}{c}\text { Significant/ } \\
\text { Insignificant }\end{array}$ \\
\hline I & 20 & 12 & 8 & 60 & \multirow{2}{*}{1} & \multirow{2}{*}{ Insignificant } \\
\cline { 1 - 5 } II & 20 & 13 & 7 & 65 & 2 & & \\
\hline III & 20 & 15 & 5 & 75 & & & \\
\hline
\end{tabular}

Table 4: Effect of therapy on Sparshaasahatva

\begin{tabular}{|c|c|c|c|c|c|c|c|c|}
\hline Group & $\begin{array}{c}\text { Number of } \\
\text { patients }\end{array}$ & Relief & $\begin{array}{c}\text { No } \\
\text { change }\end{array}$ & $\begin{array}{c}\text { Percentage } \\
\text { of relief }\end{array}$ & $\begin{array}{c}\text { Chi -Square } \\
\text { value }\end{array}$ & Df & "P" value & $\begin{array}{c}\text { Significant/ } \\
\text { Insignificant }\end{array}$ \\
\hline I & 20 & 15 & 5 & 75 & & & \\
II & 20 & 15 & 5 & 75 & 0.196 & 2 & & Insignificant \\
\hline III & 20 & 16 & 4 & 80 & & & \\
\hline
\end{tabular}

Table 5: Comparison of Efficacy of Three Groups on RA Factor

\begin{tabular}{|c|c|c|c|c|}
\hline Source of variation & Df & Sum of Squares & Mean sum of squares & \multirow{2}{*}{ F-ratio } \\
\hline Between the groups & $3-1=2$ & 13.54 & 6.77 & \multirow{2}{*}{3.65} \\
\hline Error & $59-2=57$ & 105.51 & 1.85 & \\
\hline Total & $60-1=59$ & 119.05 & & \\
\hline
\end{tabular}

Table 6: Overall Effect of the Therapy

\begin{tabular}{|c|c|c|c|c|c|c|}
\hline & \multicolumn{2}{|c|}{ Group I } & \multicolumn{2}{c|}{ Group II } & \multicolumn{2}{c|}{ Group III } \\
\hline Results & $\begin{array}{c}\text { Number of } \\
\text { patients }\end{array}$ & $\begin{array}{c}\text { Percentage } \\
\text { of Relief }\end{array}$ & $\begin{array}{c}\text { Number of } \\
\text { patients }\end{array}$ & $\begin{array}{c}\text { Percentage } \\
\text { of Relief }\end{array}$ & $\begin{array}{c}\text { Number of } \\
\text { patients }\end{array}$ & $\begin{array}{c}\text { Percentage } \\
\text { of Relief }\end{array}$ \\
\hline Complete remission & 0 & 0 & 0 & 0 & 0 & 0 \\
\hline Markedly improved & 13 & $65 \%$ & 16 & $80 \%$ & 17 & $85 \%$ \\
\hline Improved & 7 & $35 \%$ & 4 & $20 \%$ & 3 & $15 \%$ \\
\hline Unchanged & 0 & 0 & 0 & 0 & 0 & 0 \\
\hline
\end{tabular}

\section{DISCUSSION}

A significant reduction in the time duration of morning stiffness, shotha, sparshaasahatva, rheumatoid arthritis titer, CRP, ESR was observed; however the grip strength was significantly increased. There was no significant difference in the results of three groups on Sandhistabdhata, Sparshaasahtva, Angamarda, Trishna, Alasya, Gourav and Shoonata Anganam; so all three groups' works almost similarly on these lakshanas. Group I was more effective in Angamarda, Aruchi, Jwar, Apaka. Group II was effective in all pratyatma lakshanas as compare to Group I. Group III was highly effective in all lakshanas as compare to other two groups. The effect of group III i.e. Bhallatakadi churna with Eranda Tail was for better in comparison to the other two groups.

\section{Probable mode of action of drugs Bhallatakadi Churna}

Action of drug deepana and ama pachana is by Laghu, Ruksha, Tikshna Guna, Katu, Tikta Rasa, Ushna Virya, Vatakaphashamaka, Vedanaprashamana and Shothahara action. It replenishes and rejuvenates the impaired 
Dhatus by Rasayana action of Bhallataka and Haritaki and also gives nourishment to them. ${ }^{8}$ Drug may acts as antioxidant, anti-inflammatory, analgesic, anti-arthritic, immunosuppressive and immunomodulatory. ${ }^{9}$

\section{Eranda Tail}

Due to Madhura, Katu, Kashaya rasa, Ushna virya, Madhura vipak, Eranda taila is having Vata-kaphashamaka property. ${ }^{10}$ Bhavmishra praises eranda sneha by comparing it to the lion which kills the elephant of amavata causing diseased condition of body. ${ }^{11}$ Content of Eranda, tricinolein is mainly responsible for purgative effect. Castor beans contains tocopherol and vitamin $\mathrm{E}$ having anti-inflammatory property. ${ }^{12}$ Both drugs play major role as Anti inflammatory and analgesic as they having shothahara and vedanaprashamana Karma. They show significant reduction in R.A. Factor, E.S.R. and C.R.P. levels.

\section{CONCLUSION}

Based on the present study, it can be concluded that Bhallatakadi churna and Eranda Tail has better improvement in most of the symptoms and also decreased ESR, RA Titer. Trial drugs in this study seem to be a very good combination of Amapachak, Agnivardhak, Shothaghna, Vedanashamak and Rasayana dravyas.

\section{REFERENCES}

1. Patwardhan BK, Saraf MN and Ghooi RB. Studies on mechanism of action of Semicarpus anacardium Linn., Indian J. physiol. Pharmacol 1990; 27(2): 166-170.

2. Sharma AK and Singh RH. Clinical evaluation of Amrita Bhallataka as Naimittik Rasayana in treatment of (Amavata) Rheumatoid Arthritis, J. Res. Indian Med 1981; Vol. II: 296-307.

3. Malaviya AN, Kapoor SK, Singh RR, Kumar A, Pande I. Prevalence of rheumatoid arthritis in the adult Indian population. Rheumatology International 1993; 13(4): 131-134. http://dx.doi.org/10.1007/BF00301258

4. Vaidya Shrilaxmipatishastri, Yogaratnakar, Amavatchikitsa, Choukhambha Prakashan, Varanasi, edition; 2009. p. 567.

5. Vaidya Shrilaxmipatishastri, Yogaratnakar, Amavatchikitsa, Choukhambha Prakashan, Varanasi, edition; 2009. p. 571.

6. BK Mahajan. Methods in Biostatistics, Jaypee Brothers Publications, edi. $7^{\text {th }} ; 2010$. p. $134,138,154$.

7. Professor Krishnachand Chunekar, Bhavprakash Nighantu, Choukhambha Bharati Akadami, edi; 2010. p. 134.

8. Dr Brhmanand Tripathi, Charak Samhita part II, edition, choukhambha surbharati prakashan, chapter 1; 2005. p. 36.

9. Database on Medicinal plants used in Ayurveda and Siddha, CCRAS Dept. of Ayush 2008; 5: 9-10.

10. Vaidya Shrilaxmipati shastri, Yogaratnakar, Amavatchikitsa, Choukhambha Prakashan, Varanasi, edition; 2009. p. 571.

11. Bhavmishra, Bhavaprakash, Choukhambha Publication, Madhyamkhand, chapter 26, shlok no.50; 2005. p. 286.

12. Murakami Y, Kawata A, Koh T, Seki Y, Tamura S, Katayama T and Fujisawa S. Inhibitory Effects of Tocopherols on Expression of the Cyclooxygenase-2 Gene in RAW2 64. Cells Stimulated by Lipopolysaccharide, Tumor Necrosis Factor- $\alpha$ or Porphyromonas gingivalis Fimbriae. In Vivo 2013; 27(4): 451-458.

Cite this article as:

Khot Varsha Sadashiv. Comparative clinical study of Bhallatakadi churna and Eranda sneha in the management of Amavata with special reference to Rheumatoid arthritis. Int. J. Res. Ayurveda Pharm. 2015;6(1):35-38 http://dx.doi.org/10.7897/2277-4343.0619 